\title{
Coming in from the cold
}

\section{Science in the Arctic cries out for better coordination — perhaps modelled on what happens in Antarctica.}

$\mathrm{t}$ is abundantly clear that the Arctic ice-cap, land and ocean play an important role in the climate dynamics of our entire planet. The region has long been one of intense interest to ecologists, atmospheric researchers, climate scientists and meteorologists. And it is now accepted that the Arctic - vaguely defined as the lands and oceans inside the Arctic Circle - is particularly vulnerable to global change.

Two forthcoming events - the G8 summit in St Petersburg, Russia, in July and next year's celebration of International Polar Year - provide vital opportunities for scientists to make the case for a more concerted, international effort to study this desolate yet fascinating region.

Sea-ice and glacier retreat, permafrost melting, carbon fluxes, vegetation changes, biodiversity and species adaptation to climate change are just some of the phenomena that make the region so interesting, and scientists are only just beginning to understand the relationships between them. Their efforts to do so can surely benefit the Sami, the Inuit and other indigenous people living in the region, whose delicate environments are under siege from pollution, ozone depletion and various human health problems. They can also help the rest of us, most obviously by contributing to our understanding of climate change.

The region's importance with regard to this issue was reiterated in the 2004 Arctic Climate Impact Assessment, a literature review that captured the frantic pace of Arctic warming over the past century and its effects on plants, animals and people. It also charted how changes there could ripple across the entire the planet (see page 146).

The assessment report, which drew considerable public attention, was the culmination of various research activities that were ignited half a century ago by the 1957-58 International Geophysical Year, which focused on polar research issues. The forthcoming International Polar Year, in 2007-08, will give polar researchers a chance to showcase their work and plan new approaches to further enhance our understanding of the Arctic.

Despite the stark findings of the 2004 climate assessment, the eight nations with territory north of the Arctic Circle - Russia, Canada, the United States, Denmark (on behalf of Greenland), Iceland,
Finland, Norway and Sweden - remain too passive in their approach to coordinating polar research. Their benign neglect has led to the gradual deterioration of parts of the network of meteorological stations in the Arctic (see page 133). Better baseline support for such monitoring would cost little, but would make a huge difference to Arctic researchers of all disciplines.

As part of its contribution to International Polar Year, Canada has allocated about Can $\$ 90$ million (US\$80 million) for this and related projects. Other countries, including the United States and Russia, have promised to improve Arctic and Antarctic monitoring. Scientists should check that these pledges are properly implemented.

By and large, scientists working in the Arctic are well connected with each other. But in contrast with Antarctica, where a 1959 international treaty obliges its signatories to collaborate in scientific research, there is no political framework for collaboration on Arctic research. The governments involved discuss regional issues through the Arctic Council, but this has no formal provision for cooperation in research.

\section{"In contrast with Antarctica, there is no political framework for collaboration on Arctic research."}

Contacts between Russia and the other nations with territory there improved after the end of the cold war. But many parts of Russia, which has by far the largest Arctic territory, are still not easily accessible to scientists, and there aren't enough truly international projects in the region.

Climate change will be on the agenda at the G8 summit, and the meeting provides an opportunity to improve the links between the large Arctic research communities of Russia, the United States and Canada. Leaders at the summit should commit to closer and more open collaboration on the model that has been tried and tested in the Antarctic.

Russia, which chairs the Arctic Council until the end of this year, should use its leadership to set up a council working group on pan-Arctic research that could address such issues as the availability of research permits and the maintenance of infrastructure for monitoring conditions in the region.

\section{Special provision}

\section{Some research centres are more equal than others.}

rom a distance, it sounds like an event worth celebrating. At Westminster on 4 May, British government officials and scientists gathered to toast the Tyndall Centre for Climate Change Research. In its first five years, the Norwich-based centre has brought together social and natural scientists and produced internationally respected work on the options that exist for responding to climate change. The gathering marked the award of another three years of support for the centre.

But behind the scenes, things aren't quite as rosy as they appear. One of Britain's more successful interdisciplinary research centres, the Tyndall centre is in fact facing a cut of some $15 \%$ in the real value of its income. Its research programmes will be reduced in scale and its $\mathrm{PhD}$ studentship programme abandoned. It also faces an uncertain future when current funding expires in 2009.

The Tyndall centre is a victim of two sets of circumstances that 
are squeezing permanent research centres of its type. Until last year, the Treasury made special provision to protect the Tyndall centre's income. When that funding expired, the three research councils that oversee the centre, led by the Natural Environment Research Council (NERC), brought in outside experts to help decide what should happen next. But staff at the Tyndall feel that they lost out in this review because their work cuts across the expertise of the councils and the reviewers.

Additionally, all UK research agencies are under pressure to divert funding from permanent centres (such as the Tyndall) to the more flexible and efficient mechanism of individual investigator grants. In the past year, in various different circumstances, the National Institute for Medical Research (run by the Medical Research Council), the NERC's Centre for Ecology and Hydrology, the Tyndall centre and the John Innes Centre, a plant-science institute also based in Norwich, have all come under pressure from this general preference.

The emphasis on individual grants is generally a good thing. But it can be taken too far: unlike, say, France or the United States, Britain has already shut down its more inefficient government laboratories. It needs to retain some permanent research centres in order to support important government functions, such as managing public health and the environment.

The NERC would argue that the Tyndall centre has already done a large part of its job by helping to build interdisciplinary research capacity. After eight years, it might make sense to fund further work through competitive grants; in Britain, these can be administered by more than one research council to support genuinely interdisciplinary projects. The NERC would also argue that its funding decisions have been reached after review of the Tyndall centre's work by independent experts.

However, the government badly needs the kind of research in which the Tyndall centre excels to help it make decisions about climate change. The centre's longterm survival would guarantee that this work keeps getting done. As well as maintaining the flow of useful reports, it would also provide a home for young researchers who wish to specialize in such interdisciplinary
"The government badly needs the kind of research in which the Tyndall centre excels to help it make decisions about climate change." work but might struggle to find a career path in an atmosphericphysics or economics department.

Similar arguments apply at the UK Energy Research Centre, based in London, another cross-council project, which will see its own pot of dedicated funding expire in 2009. Its fate will largely rest on independent peer review. If it scores as highly as the Tyndall centre, the government should make special provision for both to guarantee their respective futures.

\section{Let the data flow}

\section{US legislation could fill a gap in drought research.}

C ompared with other types of natural disaster, drought rarely gets the public attention it merits. In east Africa, it is currently devastating entire nations - again. Even in wealthy nations it has a huge human and economic impact. Legislation currently before the US Congress acknowledges the potential role of science in drought preparation and mitigation.

The legislation would create a National Integrated Drought Information System (NIDIS) within the National Oceanic and Atmospheric Administration. The system would collect drought data, make forecasts and communicate information to the public. According to a bill introduced by Representative Ralph Hall (Republican, Texas), funding would start at \$12 million next year (a 50\% increase over current federal drought funding), rising to \$18 million in 2012. Senator Ben Nelson (Democrat, Nebraska) has introduced a similar bill in the Senate.

NIDIS has enthusiastic support from western states, which bore the brunt of a US drought that ran from 1999 to 2004 and was among the worst for a century. As global warming kicks in, such events are likely to become more frequent and more severe.

Drought forecasting has made real advances in the past decade. The National Drought Mitigation Center at the University of NebraskaLincoln has taken the lead in producing an online US Drought Monitor, which tracks the scale and extent of drought nationwide.

Yet much more could be done. Today the relevant data come from a patchwork of federal, state, regional and local agencies. The
Department of Agriculture contributes snow-pack measurements, reservoir data come from the US Army Corps of Engineers and the Bureau of Reclamation, and the US Geological Survey (USGS) collects groundwater and stream-flow information. NIDIS could pull together, standardize and interpret the data they produce. Drought preparation would benefit from the same kind of focus that the National Hurricane Center in Florida currently provides.

NIDIS would also work to patch holes in the existing data network. Scientists involved in drought prediction could use better maps of soil moisture, for example. And experimental products such as the Vegetation Drought Response Index — designed by the USGS and other agencies to map the effects of drought at high resolution - could be developed more fully.

Funding for drought research may face some resistance from those suspicious that it is a ploy by western states to get some of
"Drought preparation would benefit from the same kind of focus that the National Hurricane Center in Florida currently provides." the money that now goes to places hit by tornadoes and hurricanes. And all the research in the world won't help political leaders prepare for drought unless they come to grips with the contentious problem of water use in the West.

But it would be irresponsible not to learn more about the threat. Globally, there is no question that drought receives less attention than its dreadful consequences merit. Drought is slow, sometimes hard to define, and doesn't look spectacular on television. Senator Nelson has resorted to naming the recent drought in his state 'Drought David' in an attempt to raise awareness. Establishing NIDIS would be an even better idea. 